AGRICULTURE AND BIOLOGY JOURNAL OF NORTH AMERICA

ISSN Print: 2151-7517, ISSN Online: 2151-7525, doi:10.5251/abjna.2012.3.11.435.438

(C) 2012, ScienceHuß, http://www.scihub.org/ABJNA

\title{
Piscicidal effect of tobacco (Nicotiana tobaccum) leaf dust on african giant catfish (Heterobranchus bidorsalis) fingerlings. \\ ${ }^{1}$ Temitope Jegede and Bolanle Olanrewaju.
}

\author{
Department of Forestry, Wildlife and Fisheries Management, Ekiti State University, Ado Ekiti, \\ Nigeria. \\ Corresponding author's e-mail: temitopejegede@yahoo.com
}

\begin{abstract}
Acute toxicity of Nicotiana tubaccum leaf dust on Heterobranchus bidorsalis fingerlings $(6.52 \pm 0.5 \mathrm{~g})$ was conducted using static bioassay tests over a period of 96 hour. The range finding test was used to determine the lethal concentration of the botanical on $\mathrm{H}$. bidorsalis and was found to induce varying behavioral response in the fish. The $96 \mathrm{~h}$ median lethal concentration, $\mathrm{LC}_{50}$ of $0.40 \mathrm{~g} \mathrm{~L}^{-1}$ was determined graphically. A concentration dependent relationship was established for the effect of the toxicants on the test organisms. Percentage survival of the test organisms followed a regular pattern increasing with decreasing concentration. Prior to death, fish exhibited marked behavioural changes like hyperventilation, erratic swimming (vertical/spiral uncoordinated swimming movement) and settling at the bottom which revealed sensitive indicators of physiological stress in fish. Histological changes in organs (gill, liver and kidney) of $H$. bidorsalis fingerlings in the definitive test disclosed; congestion of blood vessel of the gill, proliferation of mucos cells, proliferation in the epithelium of the gill filament, aggregation of inflammatory cells which are related to gill function disorders. Liver shows vacuolar degeneration, diffused vacuolation in hepatocyte, inflation of the liver, vacuolation and fibrosis in the hepatocellular parenchyma and kidney shows degeneration of instertitial tissue, glomerular shrinkage, degeneration of tubular epithelia cell and severe vacuolation and lesion in kidney cell.

Key words: Piscicidal, Nicotiana tobaccum and Heterobranchus bidorsalis
\end{abstract}

\section{INTRODUCTION}

Piscicides are often used to control competing species in fish production especially in small water bodies/enclosures, eradicate fish to control parasites and conserve or restore native species but their uses are not encouraged because of their toxicity to aquatic organisms and the degradation of the environment (Fafioye 2005). Piscicidal plants are frequently use by fisher folks of various African countries extensively for capturing fish and reported to be of high potency (Fafioye 2001 and Fafioye et al., 2004).

Fish farmers in Nigeria have persistently and indiscriminately abused these natural plant piscicides by using much higher concentrations than necessary, causing mass mortality of fish in ponds, contaminating the freshwater bodies and affecting non target organisms.

Tobacco is the common name for the plant Nicotiana tobacum. It is a native of tropical and subtropical America but it is now commercially cultivated worldwide (Knapp 2004). Tobacco contains the following phytochemicals: Nicotine, Anabasine (an alkaloid similar to the nicotine but less active), Glucosides (tabacinine, tabacine), 2,3,6-Trimethyl1,4-naphthoquinone, 2-Methylquinone, 2Napthylamine, Propionic acid, Anatalline, Anthalin, Anethole, Acrolein, Anatabine, Cembrene, Choline, Nicotelline, Nicotianine and Pyrene and they are generally recognized as being narcotic. This property makes it useful as narcotics, mulluscicides, piscicides, an anesthetic and pesticide (Aleem, 1983, Agbon et al., 2002).

The genus Heterobranchus is endemic to Africa (Teugel 1982). Heterobranchus bidorsalis is the second most important Clariid catfish used in aquaculture in Nigeria (Adewumi 2005; Vanden Bossche and Bernacsek 1990 and Fagbenro et al., 1993). This study therefore is aimed at determining the lethal concentration (LC50) value of Heterobranchus bidorsalis fingerlings exposed to varying levels of Nicotiana tobaccum leaf dust and to determine the effects of Nicotiana tobacum leaf dust on histopathology of gills, liver and kidney tissues of Heterobranchus bidorsalis fingerlings. 


\section{MATERIALS AND METHODS}

Two hundred apparently healthy fingerlings of Heterobranchus bidorsalis mixed sex and the same brood stock, mean weight and length of $(6.52 \pm 0.5 \mathrm{~g})$ and $(7.25 \pm 1.0 \mathrm{~cm})$ respectively were procured from Helen fish farm Ondo, Ondo State, Nigeria. They were transported live to Fisheries Management laboratory of Ekiti State University, Ado Ekiti, Ekiti State in a 50 litre capacity plastic container, half filled with pond water between 1700-1730h. They were later stocked in circular plastic tanks of 60-litre capacity where they are allowed to acclimatize for 7 days. Ten $H$. bidorsalis fingerlings $(6.52 \pm 0.5 \mathrm{~g})$ were stocked into each plastic tank, with three replicates per treatment. The leaves of $N$. tobaccum were collected around Faculty of Agricultural Sciences Farm of Ekiti State University Ado Ekiti, shade-dried at ambient and milled into fine particle size $(<250$ $\mu \mathrm{m})$; and kept in a dry, clean, air-tight transparent plastic container. The treatments are: Treatment 1, $0.2 \mathrm{~g} \mathrm{~N}$. tubaccum $/ \mathrm{L}^{-1}$ of water; Treatment $2,0.4 \mathrm{~g} \mathrm{~N}$. tobaccum $/ \mathrm{L}^{-1}$ of water; Treatment $3,0.6 \mathrm{~g} N$. tobaccum $/ \mathrm{L}^{-1}$ of water; Treatment $4,0.8 \mathrm{~g} \mathrm{~N}$. tobaccum/ $\mathrm{L}^{-1}$ of water; and Control , $0 \mathrm{~g} \mathrm{~N}$. tobaccum $/ \mathrm{L}^{-1}$ of water. Prior to the commencement of the experiment, the fish were starved for 2 days. This is to minimize the amount of waste in the test media and to prevent organic decomposition and oxygen depletion. The experiment was conducted under standard static bioassay condition. Temperature, $\mathrm{pH}$, dissolved oxygen, and conductivity level were determined using standard methods and readings were taken at $24 \mathrm{~h}$ interval for $96 \mathrm{~h}$. At the end of the treatment period, two fish from each treatment tank were removed, weighed on a Metler top-loading balance (Model P13 8001), killed by decapitation and vital organs such as the gill, liver and kidney were removed, fixed for $24 \mathrm{~h}$ in formalin-saline solution made of equal volumes of $10 \%$ formalin and $0.9 \%$ $\mathrm{NaCl}$ solution. Histological sections of $8 \mu$ thickness were prepared following standard procedures (Chieli et al., 1995) photomicrographs were taken with Leitz (Ortholux) microscope and camera.

\section{RESULTS}

The following behaviours were exhibited during the definitive test; Erratic swimming, hyperventilation, vertical/spiral swimming positions, weakened swimming motions and settling at the bottom. Fish mortality at varying concentrations increased with increasing concentration of Nicotiana tobacco leaf dust. All fish in the control treatment survived throughout the 96 hours duration of the experiment.
There were significant losses of fish with increase in Nicotiana tobaccum concentration $(P<0.05)$. The LC50 was recorded graphically at $0.40 \mathrm{~g} \mathrm{~N}$. tobaccum $/ \mathrm{L}^{-1}$ of water (Fig. 1).

Histological changes in organs (gill, liver and kidney) of $H$. bidorsalis fingerlings (Tables 1,2 , and 3 )

Table 1: Histological changes in gills of $\boldsymbol{H}$. bidorsalis fingerlings

\begin{tabular}{|l|l|}
\hline Concentration $\mathbf{~} / \mathbf{L}$ & Histological observation \\
\hline 0 & Normal gill architecture \\
\hline 0.2 & $\begin{array}{l}\text { Congestion in the blood vessels of } \\
\text { the gill. }\end{array}$ \\
\hline 0.4 & Proliferation of the mucus cell \\
\hline 0.6 & $\begin{array}{l}\text { Proliferation in the epithelium of gill } \\
\text { filament }\end{array}$ \\
\hline 0.8 & Aggregations of inflammatory cells \\
\hline
\end{tabular}

Table 2: Histological changes in liver of $\boldsymbol{H}$. bidorsalis fingerlings

\begin{tabular}{|l|l|}
\hline Concentration $\mathbf{~} / \mathbf{L}$ & Histological observation \\
\hline 0 & $\begin{array}{l}\text { Normal hepatocellular architecture } \\
\text { and no visible lesion }\end{array}$ \\
\hline 0.2 & Vacuolar degeneration \\
\hline 0.4 & Diffuse vacuolation of hepatocyte. \\
\hline 0.6 & Inflammation of liver cells. \\
\hline 0.8 & $\begin{array}{l}\text { Vacuolation and fibrosis in the } \\
\text { hepatocellular parenchyma. }\end{array}$ \\
\hline
\end{tabular}

Table 3: Histological changes in kidney of $\boldsymbol{H}$. bidorsalis fingerlings

\begin{tabular}{|l|l|}
\hline Concentration $\mathbf{~} / \mathbf{L}$ & Histological observation \\
\hline 0 & $\begin{array}{l}\text { Normal kidney cell and no } \\
\text { visible lesion }\end{array}$ \\
\hline 0.2 & $\begin{array}{l}\text { Degeneration of interstitial } \\
\text { tissue }\end{array}$ \\
\hline 0.4 & Glomerular shrinkage \\
\hline 0.6 & $\begin{array}{l}\text { Degeneration of the tubular } \\
\text { epithelial. }\end{array}$ \\
\hline 0.8 & $\begin{array}{l}\text { Severe vacuolation and lesion } \\
\text { in kidney cell. }\end{array}$ \\
\hline
\end{tabular}




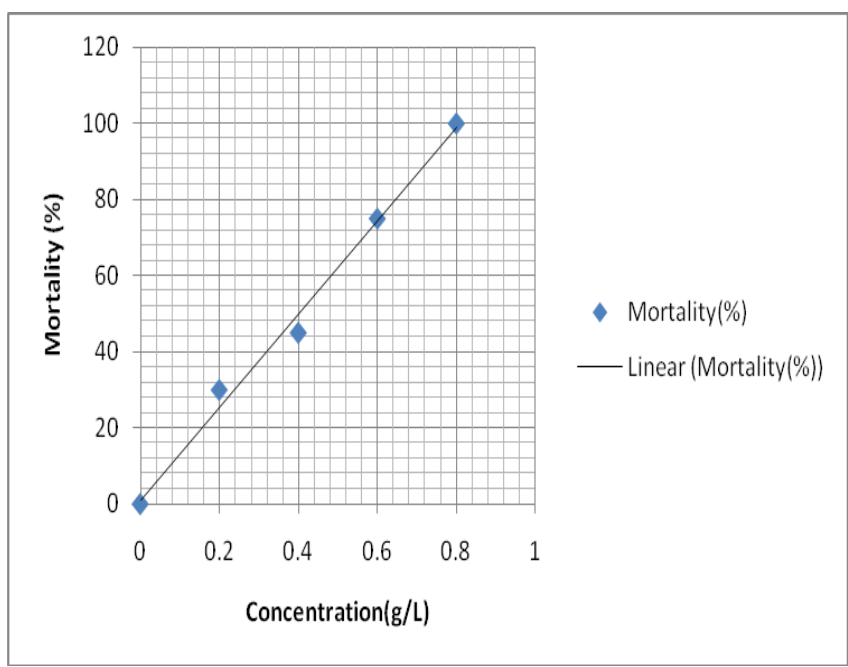

Fig. 1: Effect of Nicotiana tobaccum on fingerlings of Heterobranchus bidorsalis.

At the expiration of the experiment (96hrs) the following results were gotten, dissolved oxygen level (DO2) level decrease with increase in concentration of $N$. tobaccum leaf dust, water temperature also increase with increasing level of $N$. tobaccum and lastly $\mathrm{pH}$ decreases with increase level of $N$. tobaccum.

\section{DISCUSSION}

This study revealed that fish exposed to $N$. tobaccum exhibit marked behavioural changes like erratic swimming, hyperventilation, vertical swimming motions and settling at the bottom which demonstrated a sensitive indicator of physiological stress in fish. In a similar study, Kori-Siakpere and Oviroh (2011) reported similar behavioural changes in Clarias gariepinus subjected to Nicotiana tobaccum leaf dust toxicity. This is also corroborated by Agbon et al., (2002) which observe stressful behaviours in Oreochromis niloticus juvenile exposed to Nicotiana tubaccum leaf dust and explained that it may be as a result of the respiratory impairments due to the effect of tobacco on the gills, which consequently reduces respiratory activity in the fish .Also fishes exposed to toxicants undergo stress, which is a state of re-established homeostasis, a complex suite of mal-adaptive responses (Chrousos, 1998). Under stress

physiological/biochemical responses may be compromised, becoming detrimental to the fish's health and well being at which point the fish is termed distressed(Barton and Iwama, 1991).
The inability of the gill surface to actively carry out gaseous exchange might be responsible for the recorded mortalities which is shown to be dependent on the concentration of the $N$. tobaccum leaf dust. The decline in $\mathrm{pH}$ with increase in exposure time is due to production of acidic metabolites.

Histological changes noticed in the gill, liver and kidney of $H$. bidorsalis fingerlings used in this study showed varying degrees of alterations (Tables 1, 2 and 3), which are attributable to some clinical factors.

The higher the concentration of $N$. tobaccum the more severe the adverse effects to the fish organs (gill, liver and kidney).Mortalities recorded in this study could be attributed to the degeneration and malfunctioning of the various organs due to the toxic effect of $N$. tobaccum. This is corroborated by Fagbenro and Akinduyile (2011) in a similar study on the toxicity of aqueous Morinda lucida leaf extracts to Oreochromis niloticus.

Finally, this study had shown the median lethal level (LC50) for Heterobranchus bidorsalis fingerlings exposed to Nicotiana tobaccum leaf dust toxicity to be $0.40 \mathrm{~g} / \mathrm{L}$ also revealed are the various histological alterations, hence knowledge of this could help in fish pond and water management.

\section{REFRENCES}

Adewumi A. A. (2005) Catfish culture in Nigeria: progress, Prospects and Problems. Aquaculture Research, volume 36. pp. $479-585$.

Agbon A. O., Omoniyi I. T., Teko A. A. (2002). Acute toxicity of tobacco (Nicotiana tobaccum) leaf dust on Oreochromis niloticus and haematological change resulting from sub-lethal exposure. J. Aquatic. Sci. 17(1): 5-8.

Aleem S. O. (1983). Studies on escape response and survival of the gastropod mollusk. Tympanotonus fuscatus exposed to tobacco waste. Post-graduate Diploma Thesis. African Regional Aquaculture centre, Port-Harcourt, Nigeria.

Barton, A. B. and G. K. Iwama (1991). Physiological changes in fish from stress in aquaculture with emphasis on the response and effects of corticosteroids. Ann. Rev. Fish Dis., 1: 3-26.

Chieli E, Romiti N, Cervelli F, and Tongiani R (1995) Effects of flavonols on P-glycoprotein activity in cultured rat hepatocytes. Life Sci 57: 1741-1751.

Chrousos, G. P. (1998). Stressors, stress and neuroendocrine integration of the adaptive response. Ann. N. Y. Acad. Sci., 851: 311-335. 
Fafioye O. O. (2005) Plants with piscicidal activities in southwestern Nigeria. Turkish Journal of Fisheries and Aquatic Sciences 5: 91-97.

Fafioye O. O., Adebisi A. A. and Fagade S.O. (2004) Toxicity of Parkia biblobosa and Raphia vinifera extracts on Clarias gariepinus juveniles. Afri. $J$. Biotechnol., 3:627-630.

Fafioye O. O. (2005) Plants with Piscidal Activities in Southwestern Nigeria. Turkish Journal of Fisheries and Aquatic Sciences. 5:91-97

Fagbenro O. and Akinduyite I. (2011) Acute toxicity of aqueous Morinda lucida leaf extracts to Oreochromis niloticus. Proceedings of $9^{\text {th }}$ International Symposium on Tilapia in Aquaculture(Eds. Liu Liping and Kelvin Fitzsimmons),pp 46-51. Shanghai, China

Fagbenro, O.A., Adedire, C.O., Owoseeni, E.A. and Ayotunde, E.O. (1993). Studies on the biology and aquacultural potential of feral catfish, Heterobranchus bidorsalis (Geoffroy Saint Hilaire 1809) (Clariidae). Tropical Zoology 6: 67-79.

Kori-Siakpere O. and Oviroh E. O. (2011) Acute toxicity of tobacco (Nicotiana tobaccum) leaf dust on the African catfish: Clarias gariepinus (Burchell, 1822). Archives of Applied Science Research, 3 (2): 1-7

Knapp E. (2004) Nomenclatural changes and a new sectional classification in Nicotiana (Solanaceae) Taxon. 53(1):73-82.

Teugels, G. G., (1982) Preliminary results of a morphological study of five African species of the subgenus Clarias ( Pisces: Clariidae), Journal of Natural History, 16: 439-464, 1982.

Vanden Boscche, J.-P. and Bernacsek, G.M. (1990). "Source book for the inland fishery resources of Africa: 2". CIFA Technical Paper No.18.2. FAO, Rome. 411p. 